\title{
Life Cycle Assessment of Waste-to-Energy: Energy Recovery from Wood Waste in Malaysia
}

\author{
Joo Ee Choong1, Chiu Chuen Onn ${ }^{1 *}$, Sumiani Yusoff ${ }^{2}$, Nuruol Syuhadaa Mohd ${ }^{1}$ \\ ${ }^{1}$ Civil Engineering Department, Faculty of Engineering, University of Malaya, \\ Kuala Lumpur, Malaysia \\ ${ }^{2}$ Institute of Ocean and Earth Science, Institute of Graduate Studies, \\ University Malaya, 50603 Kuala Lumpur, Malaysia
}

Received: 1 June 2018

Accepted: 2 August 2018

\begin{abstract}
This paper presents life cycle assessment for a biomass-fired power plant that utilizes recycled wood waste as fuel. Life cycle analysis of the wood WtE plant was done using SimaPro software using an Ecoinvent 3.4 database and ReCiPe Midpoint impact assessment method. The main concern was given to climate change factor through the evaluation of GHG emissions of the wood WtE plant. The results showed that $31.9 \mathrm{~g} \mathrm{CO}_{2}$ eq of GHG emissions are emitted for every $\mathrm{kWh}$ of electricity generated by the wood WtE plant. The emissions value was $96.1 \%$ lower than the electricity generated by the national grid, which is $820 \mathrm{~g} \mathrm{CO}_{2}$ eq of GHG emissions. In conclusion, WtE emerged as a sustainable approach in disposing of solid waste while reducing GHG emissions and increasing the share of renewable energy in energy mix simultaneously. A scenario was created to show the relationship between the percentage of carbon emissions reduction that is in line with Malaysia's commitment to reduce GHG emissions by up to $45 \%$ by 2030 , hence making the utilization of biomass and solid waste a reliable source of renewable energy as targeted by SEDA Malaysia.
\end{abstract}

Keywords: waste-to-energy; solid waste; life cycle assessment; biomass fired power plant; greenhouse gases

\section{Introduction}

Solid waste management is one of the most serious and controversial issues encountered by the local and regional authorities of Malaysia. Solid waste generation

*e-mail: onnchiuchuen@um.edu.my for the whole of Malaysia is about 33,000 tonnes per day in 2012 and 38,200 tonnes per day in 2016 [1]. Other than waste generation by household, waste generation by industrial, commercial and institution (ICI) also encompasses municipal waste, but construction and demolition waste, as well as industrial scrap, are excluded [2]. ICI waste includes food wastes, packaging, housekeeping wastes, paper, cardboard, plastics, wood, glass and metals. The generation of solid waste in 
Malaysia is estimated to reach 45,900 tonnes per day in 2020, whereas 16.76 million tonnes of waste is expected to be generated annually by 2020 [1]. Solid waste management will be a tough challenge since Malaysia depends solely on landfilling for waste disposal. Direct disposal of $91.3 \%$ of total solid waste generated in 2012 has resulted in more than 10 million tonnes of solid waste being disposed of in landfills [1]. In $2016,82.5 \%$ of total solid waste generated, which is approximately 13 million tonnes of solid waste, is being disposed of in 161 landfills across Malaysia, with $17.5 \%$ being recycled [1]. Undeniably, landfill is always the best disposal method, especially in developing countries, due to its economically simple management. Although landfilling offers an economical waste disposal method, tremendous increases in solid waste disposal will accelerate environmental degradation through air and water pollution if not properly managed.

Out of the total 33,000 tonnes of solid waste generated per day as reported in 2012, ICI waste generation is about 11,500 tonnes while the average ICI per capita waste generation is $0.41 \mathrm{~kg} / \mathrm{capita} /$ day. Generally, industrial waste in Malaysia mainly consists of plastic, paper, food waste and wood, which is accumulated for $39.1 \%, 35.1 \%, 5.8 \%$ and $4.5 \%$ respectively [2]. Energy content of ICI waste is generally high except for food waste, which has high moisture content. Plastic, rubber, leather, cardboard and wood wastes have lower calorific value (LCV) more than $14 \mathrm{MJ} / \mathrm{kg}$. The average calorific value for wood waste is between $16.488 \mathrm{MJ} / \mathrm{kg}$ (lower heating value, wet basis) and $20.092 \mathrm{MJ} / \mathrm{kg}$ (higher heating value, dry basis) [2]. A better option should be available to dispose of these wastes instead of landfilling.

Waste-to-energy (WtE) has emerged as one of the solutions for solid waste management in Malaysia. Waste-to-Energy includes gasification, incineration and pyrolysis processes that thermally treat solid waste and directly recover energy in the form of electricity and/or heat. Also, WtE involves bio-chemical processes such as landfill gas recovery and anaerobic digestion that converts chemical energy in solid waste to yield products of high energy value, for example methane [3]. WtE systems fit well within the concept of 'zero waste,' along with the recycling and reuse of the MSW as WtE can provide additional economic benefits in recovering up to $90 \%$ of ferrous materials from both waste-stream inflow and bottom-ash outflow [4]. Studies suggest that waste incineration power generation is a better option than landfill gas utilization from the perspective of GHG emission reduction, while some studies have suggested that the environmental impact of MSW management can be reduced by $\mathrm{WtE}$ [5]. WtE has the potential to solve the problems of waste management, energy demand and greenhouse emissions simultaneously [6]. $\mathrm{WtE}$ is a good option for waste management as it is effective in reducing the weight and volume of waste, thus saving land space for landfilling. WtE is able to convert the waste into heat and electrical energy. Since Malaysia's climate is hot and humid throughout the year, the heat energy can be supplied to industries instead of residential heating for households. Generated electricity can be fed into the national grid and act as a source of renewable energy (RE) to curb the increasing demand for electricity generation, since electricity consumption in Malaysia has risen extensively over the past few decades along with the growth of Malaysia's population and gross domestic product (GDP). Annual electricity generation of Malaysia in 2015 is 144,565 GWh, which has increased $0.513 \%$ from $143,827 \mathrm{GWh}$ of the previous year [7]. Although both conventional and renewable sources of energy contribute to power generation in Malaysia, only a very small portion of electricity that is less than $1 \%$ is generated by renewable sources such as biomass, solar and biogas. Fossil fuels such as coal, crude oil and natural gas are the most reliable source of energy supply globally, which accumulate for $84 \%$ of global electricity production, while $88.4 \%$ of Malaysia's electricity output is generated from burning fossil fuel resources [7, 8]. Electricity generated from the combustion of fossil fuels has created various environmental issues where the primary concerns will be emissions of carbon dioxide and climate change issues. Therefore, renewable energy sources have gained more attention in the last two decades [9]. In order to promote the use of renewable energy in Malaysia, a feed-in tariff (FiT) system has been established with the enforcement of the Renewable Energy Act 2011. Under this FiT system, the Sustainable Energy Development Authority (SEDA) of Malaysia has targeted increasing renewable energy capacity up to $4,000 \mathrm{MW}$ by 2030 , during which $1,340 \mathrm{MW}$ of RE capacity is expected to be generated from biomass while $360 \mathrm{MW}$ will come from solid waste [10]. Malaysia has great biomass and wood waste resources available for immediate exploitation [11]. There are more biomass resources to be exploited in all regions of Malaysia - especially in rural areas.

Life-cycle thinking (LCT) has been introduced as a guiding principle of resource management where the strategic goal of moving toward more sustainable patterns of consumption and production has been set with a view to decoupling resource use and waste generation [12]. Tools and methods are used in quantifying and comparing the environmental impacts of providing products and services to society for sustainable development. Life cycle assessment (LCA) is a useful tool that considers the entire life cycle of a specified product from cradle to grave. It is guided by ISO 14040 (2006). LCA is a well-established research method allowing for the identification of environmental threat and evaluation of the amount of used raw materials and produced energy, as well as the amount of impurities, discharged waste and their environmental impact. LCA helps identify potential threats and establish new ways of improving environmental quality 
standards [13]. Thus, LCA is able to help the decision makers in selecting suitable strategies and comparing the energetic and environmental performances of different WtE options. Life cycle assessment is one of the most effective methods allowing for evaluation and comparison of the environmental impact of energy production of different power plants [13, 14].

This study aimed to use the life cycle assessment method to study the potential of implementing WtE technology in Malaysia. This study considers a biomass-fired power plant with a capacity of $7 \mathrm{MW}$ in Selangor, Malaysia. The WtE plant uses wood waste as fuel for electricity generation. Life cycle assessment methodology is used to evaluate the environmental impacts associated with the wood WtE plant. The environmental impacts generated by $\mathrm{WtE}$ are used to make a comparison with the national grid to determine the potential of WtE technology implementation in Malaysia.

\section{Material and Methods}

\section{Life Cycle Assessment}

Life cycle assessment (LCA) is a useful tool for determining the environmental impacts of products, services or processes, considering their entire life cycle from cradle to grave. LCA is chosen as the methodology to carry out this study to evaluate environmental impacts of wood waste to energy plant in generating electricity.

\section{Goal and Scope Definition}

The goal of this study is to identify the potential of WtE technology as an alternative of landfilling in a developing country. The focus is on the case of Malaysia, a developing country that depends solely on landfilling in solid waste management. The objectives of the study are to develop an LCA model for wood waste-to-energy plant and to evaluate the environmental impacts of wood waste-to-energy plant in generating electricity. The results will then be compared to the current national grid in generating $1 \mathrm{kWh}$ of electricity from the perspective of environmental impacts.

\section{Data Sources}

The obtained data was from a 7 MW biomass-fired power plant owned by a paper mill at Rasa, Selangor, Malaysia. This plant was the only WtE plant that utilized wood from ICI waste as fuel that enrolled in a feed-in tariff (FiT) mechanism introduced by the Malaysian government under biomass-solid waste category as

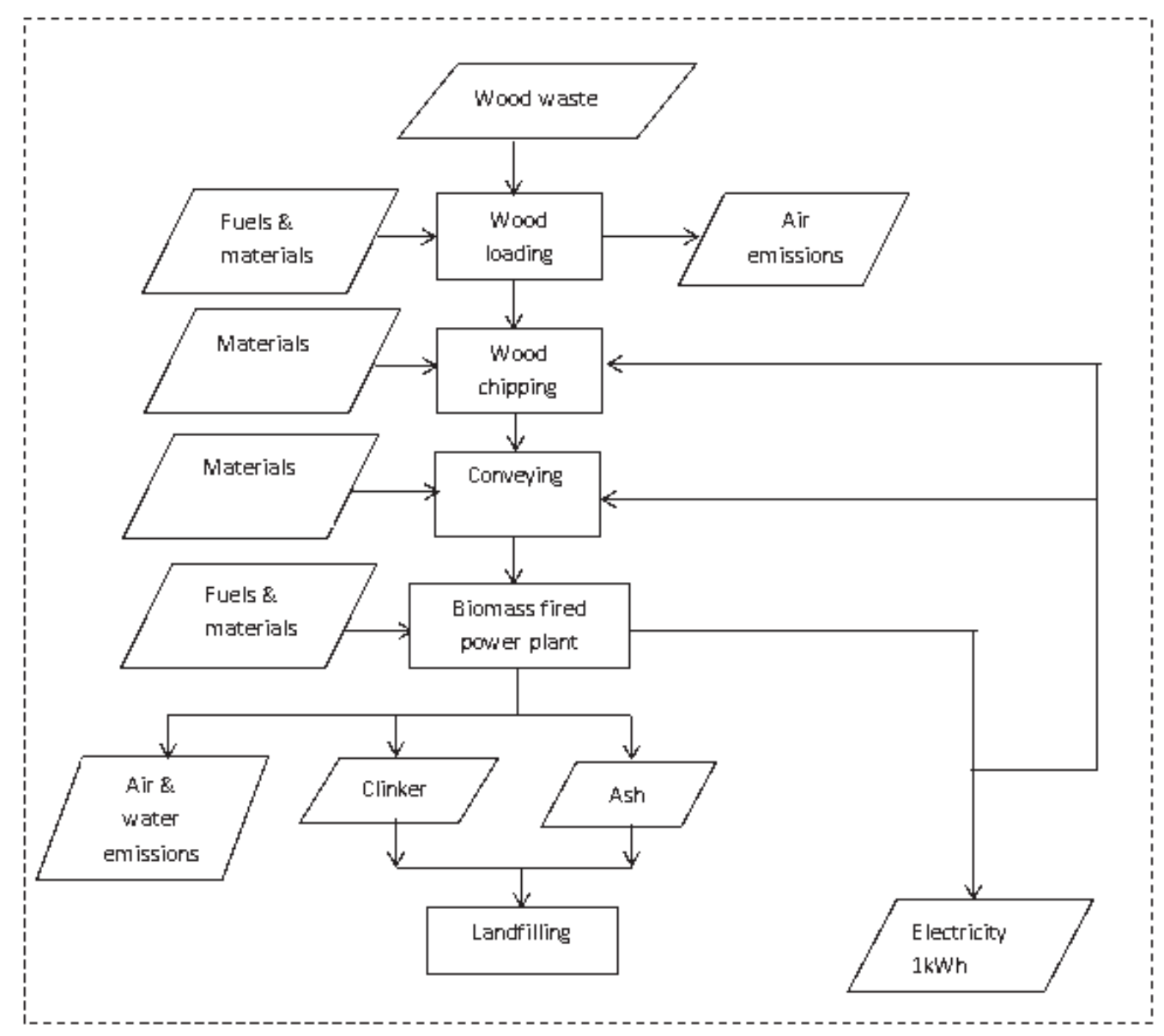

Fig. 1. The system boundary for the LCA study. 


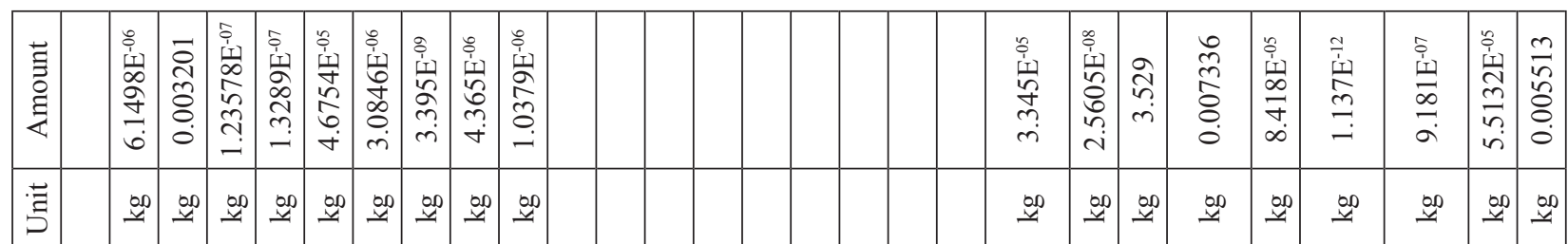

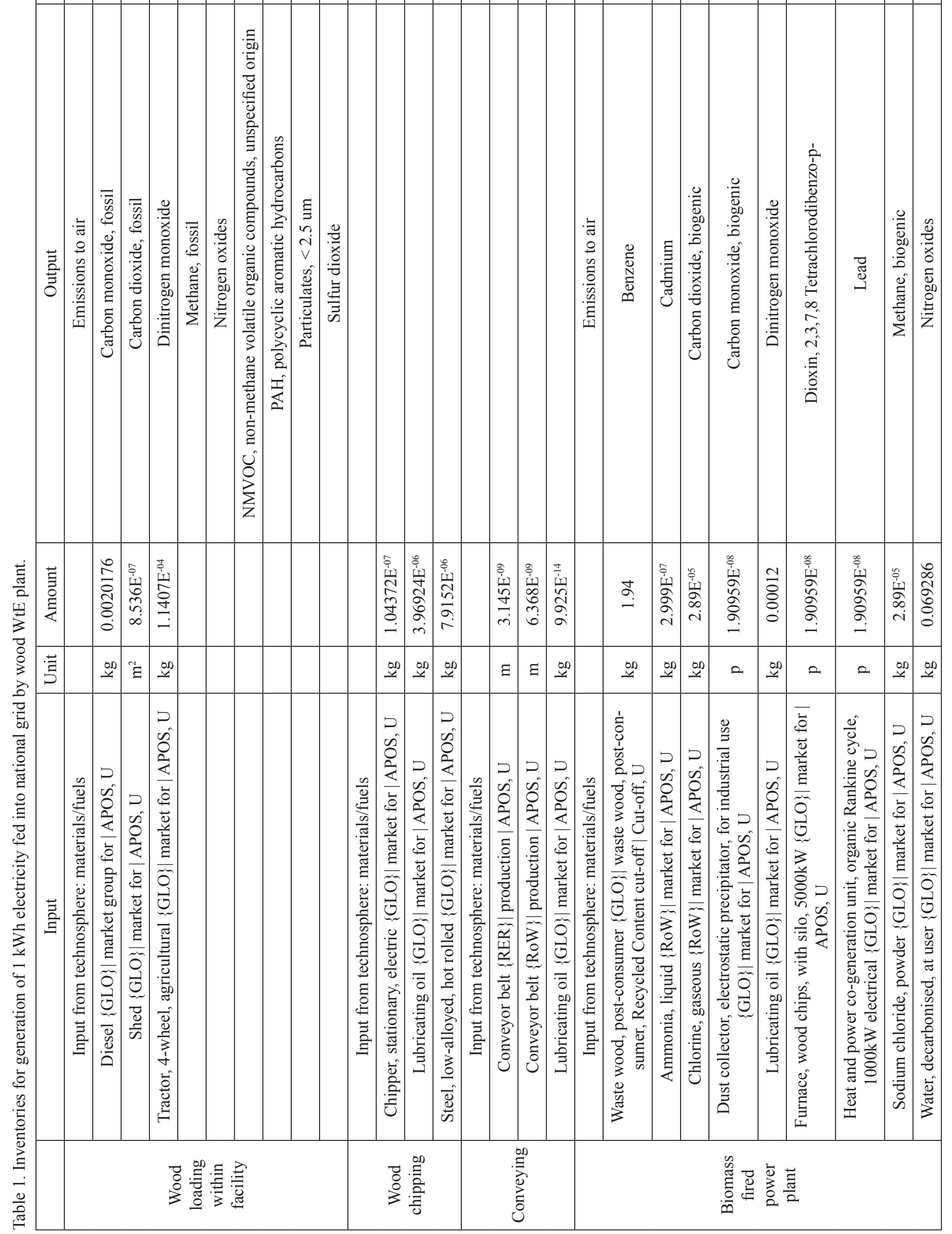




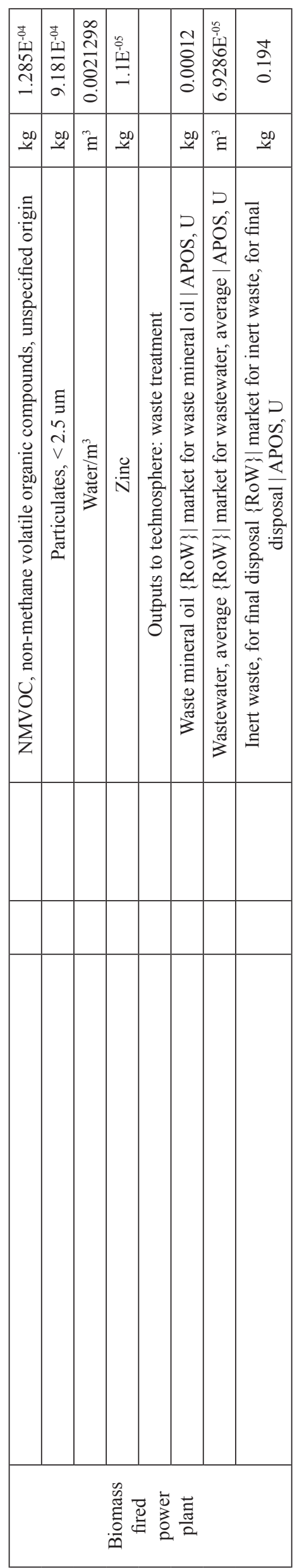

of December 2017. The data enquiries were made through a site visit from March 2017 to November 2017. There were interview sessions with the plant engineer and operator to get the actual data of the operating plant. However, some data was unobtainable due to industrial confidentiality. Hence, secondary data of case studies from the Ecoinvent database (version 3.4) were used as part of the inventories for this LCA study.

\section{System Boundary}

The boundaries of the wood waste-to-energy system incorporated the incoming of wood waste until its final discharge, including the production of steam and electricity. Only inputs and outputs relative to the operation were included. Construction and maintenance of the plant were neglected. The system boundary for this LCA study was shown in the schematic diagram in Fig. 1.

\section{Functional Unit}

The functional unit reflects the function of the investigated product. In this case study, waste wood acts as a kind of biofuel to supply heat and electrical energy. The focus is given to the potential of electricity generated by the wood WtE plant. Thus, the chosen functional unit for this LCA study is $1 \mathrm{kWh}$ of electricity generated by the wood WtE plant.

\section{Limitation and Assumption}

For this LCA model, transportation will only involve the transfer and loading of wood waste during the operation. Transport distance and route during the collection of the wood waste and final disposal of clinker to landfill are neglected. No additional fuel is added for the combustion of wood waste in boiler as the plant is operating continuously since the first ignition. The wood waste consists of all kind of wooden furniture from households, plus branches, stumps, timbers, whole trees from street or park maintenance, wood pallets, wood chips and sawdust. The wood waste that was being fed into the boiler has a moisture content of less than $25 \%$.

\section{Life Cycle Impact Assessment Methodology}

SimaPro software (version 8.5) was chosen to perform the LCA of wood WtE plant due to its reputation as an accredited LCA tool that was widely used globally. The software comes with an updated Ecoinvent database (version 3.4) libraries as well as various impact assessment methods.

Life cycle impact assessment (LCIA) methodology is the method used to determine the potential impacts of the selected attributes. Different methodologies used different approaches, but all will ultimately give 
the potential impacts associated to the study. Multiple impact assessment methods can be distinguished by midpoint and endpoint, referring to different stages in the cause-effect chain when calculating the result of LCA.

Among available LCIA methods, a selection had been made where ReCiPe Midpoint $(\mathrm{H})$ was chosen to determine the potential impacts of the wood WtE plant. The ReCiPe method converted the long list of LCI results into a limited number of indicator scores that represent relative severity on environmental impact categories. The environmental impacts are quantified based on 18 impact subcategories. Levels of indicator for this method cover three cultural perspectives:

i) Individualist (I), based on short-term interest and effective for optimism future technology development to avoid arising problems.

ii) Hierarchist $(\mathrm{H})$, considered the medium time frame, is the most common policy principles, also acts as the default model.

iii) Egalitarian (E), considered the longest time-frame, is a long-term based precautionary principle thinking; among all, Hierarchist $(\mathrm{H})$ was selected as the main goal of this study to evaluate the potential of implementing WtE technology in Malaysia, so that policy-makers may consider this choice in planning an integrated solid waste management system.

\section{Results and Discussion}

\section{Inventory Analysis}

Environmental performance of each life cycle process was evaluated by identifying inputs and outputs for every process. The inventory data was collected, calculated and then related to the functional unit for calculating the energy and material flows linked to each life cycle process and passed the system boundary. The WtE selected for this study was a biomass cogeneration power plant with a capacity of $7 \mathrm{MW}$, which utilizes recycled wood waste as fuel for generating electricity and heat. The process started after the collected wood waste reached the site until the final disposal of the ash and clinker remained from being generated during the combustion of the wood waste.

\section{Inventory Selection}

The inventory selection was made based on the LCI database that exactly or partially matched the data collected at the studied WtE plant. Missing data would be extracted from literature and case studies done by other LCA practitioners, which was available in the database. Table 1 showed the inventories for generating $1 \mathrm{kWh}$ electricity fed into the national grid by the wood WtE plant.
Results that referred to the environmental impacts will be calculated with reference of the functional unit, which was $1 \mathrm{kWh}$ of output electricity generated by the wood WtE with ReCiPe Midpoint (H) V1.13 / World Recipe H method.

\section{LCA of Wood WtE Plant}

For impacts to human health, generating $1 \mathrm{kWh}$ electricity by wood WtE plant contributed $31.9 \mathrm{~g} \mathrm{CO}_{2}$ eq to climate change, $1.65 \mathrm{E}^{-06} \mathrm{~g}$ CFC-11 eq in term of ozone depletion, $3.55 \mathrm{E}^{-04} \mathrm{~g}$ NMVOC of photochemical oxidant formation, $0.219 \mathrm{~g} \mathrm{PM}_{10}$ eq of particulate matter formation, $3.13 \mathrm{~Bq} \mathrm{U} 235 \mathrm{eq}$ of ionizing radiation and $21.7 \mathrm{~g} \mathrm{1,4-DB}$ eq of human toxicity. For impacts to the ecosystem, generating $1 \mathrm{kWh}$ from wood WtE plant caused $2.15 \mathrm{~g} \mathrm{SO}_{2}$ eq impacts to terrestrial acidification, $0.0978 \mathrm{~g} \mathrm{P}$ eq impacts to freshwater eutrophication, $0.0605 \mathrm{~g} \mathrm{~N}$ eq impacts to marine eutrophication, $6.06 \mathrm{~g}$ 1,4-DB eq impacts to terrestrial eco-toxicity, $-8.61 \mathrm{E}^{-03} \mathrm{~g}$ 1,4-DB eq of impacts to freshwater eco-toxicity, $0.591 \mathrm{~g}$ $1,4-\mathrm{DB}$ eq of impacts to marine eco-toxicity, $3.98 \mathrm{E}^{-05} \mathrm{~m}^{2} \mathrm{a}$ of impacts to agricultural land, $7.4 \mathrm{E}^{-05} \mathrm{~m}^{2} \mathrm{a}$ of impacts to urban land and $3.12 \mathrm{E}^{-04} \mathrm{~m}^{2}$ of impacts to natural land transformation. For impacts to resource availability, generating $1 \mathrm{kWh}$ from wood WtE plant caused fossil depletion, metal depletion and water depletion of $2.2 \mathrm{E}^{-05}$ $\mathrm{kg}$ oil eq, $0.00021 \mathrm{~kg} \mathrm{Fe}$ eq and $0.00311 \mathrm{~m}^{3}$ respectively.

\section{LCA of Wood WtE Plant vs. National Grid for Every $\mathrm{kWh}$ of Electricity Generation}

The environmental impact of each $\mathrm{kWh}$ of electricity generated by the wood WtE plant will be compared to the environmental impacts of every $\mathrm{kWh}$ generated from the national grid based on a previous study by Onn, C.C., et al. 2017 [15]. A total contribution of $31.9 \mathrm{~g} \mathrm{CO}_{2}$ eq GHG emissions ( $96.1 \%$ lower) was generated by the wood WtE plant, whereas $820 \mathrm{~g} \mathrm{CO}_{2}$ eq was emitted by the national grid for every $\mathrm{kWh}$ of electricity generated. The wood WtE plant would produce more impacts to human health than the current national grid for every $\mathrm{kWh}$ of electricity generation in term of ozone depletion $(33.82 \%)$ and ionizing radiation (29.01\%). However, the wood WtE plant generated slightly lower impacts in term of human toxicity (13.2\%), photochemical oxidant formation (99.99\%) and particulate matter formation $(89.05 \%)$ than the current national grid in generating $1 \mathrm{kWh}$ of electricity.

Generating $1 \mathrm{kWh}$ electricity from both wood WtE plant and the national grid resulted in low impacts to the ecosystem. The current national grid had zero impact on agricultural land occupation, urban land occupation and natural land transformation. The wood WtE plant would produce impacts of $3.98 \mathrm{E}^{-05} \mathrm{~m}^{2} \mathrm{a}$, $7.4 \mathrm{E}^{-05} \mathrm{~m}^{2} \mathrm{a}$ and $3.12 \mathrm{E}^{-04} \mathrm{~m}^{2}$ respectively in term of agricultural land occupation, urban land occupation and natural land transformation impacts. Impacts to terrestrial acidification (46.25\%), marine eutrophication 
Table 2. Impact assessment of wood WtE plant vs current national grid in generating $1 \mathrm{kWh}$ electricity.

\begin{tabular}{|c|c|c|c|}
\hline \multicolumn{4}{|c|}{ SimaPro 8.5.0.0 } \\
\hline Project & \multicolumn{3}{|c|}{ Wood WtE } \\
\hline Calculation & \multicolumn{3}{|c|}{ Impact assessment } \\
\hline Results & \multicolumn{3}{|c|}{ Analyse } \\
\hline Product & \multicolumn{3}{|c|}{ Generation of $1 \mathrm{kWh}$ electricity by wood WtE } \\
\hline Method & \multicolumn{3}{|c|}{ ReCiPe Midpoint (H) V1.13 / World Recipe H } \\
\hline Indicator & \multicolumn{3}{|c|}{ Characterisation } \\
\hline Skip categories & \multicolumn{3}{|c|}{ Never } \\
\hline Exclude infrastructure processes & \multicolumn{3}{|c|}{ No } \\
\hline Exclude long-term emissions & \multicolumn{3}{|c|}{ No } \\
\hline Sorted on item & \multicolumn{3}{|c|}{ Impact category } \\
\hline Sort order & \multicolumn{3}{|c|}{ Ascending } \\
\hline Impact category & Unit & Wood WtE & National Grid \\
\hline Climate change & $\mathrm{kg} \mathrm{CO}_{2 \mathrm{eq}}$ & 0.0319 & 0.820 \\
\hline Ozone depletion & kg CFC-11 eq & $1.65 \mathrm{E}^{-09}$ & $4.739 \mathrm{E}^{-11}$ \\
\hline Ionizing radiation & kBq U235 eq & 0.00313 & 0.0001043 \\
\hline Photochemical oxidant formation & kg NMVOC & $3.55 \mathrm{E}^{-07}$ & 0.003 \\
\hline Particulate matter formation & $\mathrm{kg} \mathrm{PM}_{10}$ eq & 0.000219 & 0.002 \\
\hline Human toxicity & $\mathrm{kg} 1,4-\mathrm{DB}$ eq & 0.0217 & 0.025 \\
\hline Terrestrial ecotoxicity & $\mathrm{kg} 1,4-\mathrm{DB}$ eq & 0.00606 & $1.262 \mathrm{E}^{-05}$ \\
\hline Terrestrial acidification & $\mathrm{kg} \mathrm{SO}_{2}$ eq & 0.00215 & 0.004 \\
\hline Agricultural land occupation & $\mathrm{m}^{2} \mathrm{a}$ & $3.98 \mathrm{E}^{-05}$ & 0.000 \\
\hline Urban land occupation & $\mathrm{m}^{2} \mathrm{a}$ & $7.4 \mathrm{E}^{-05}$ & 0.000 \\
\hline Natural land transformation & $\mathrm{m}^{2}$ & 0.000312 & 0.000 \\
\hline Marine ecotoxicity & $\operatorname{kg} 1,4-\mathrm{DB}$ eq & 0.000591 & 0.0001968 \\
\hline Marine eutrophication & $\operatorname{kg~N~eq~}$ & $6.05 \mathrm{E}^{-05}$ & 0.00011 \\
\hline Freshwater eutrophication & $\mathrm{kg} \mathrm{P} \mathrm{eq}$ & $9.78 \mathrm{E}^{-05}$ & $5.385 \mathrm{E}^{-07}$ \\
\hline Freshwater ecotoxicity & $\mathrm{kg} 1,4-\mathrm{DB}$ eq & $-8.61 \mathrm{E}^{-06}$ & $7.657 \mathrm{E}^{-06}$ \\
\hline Fossil depletion & $\mathrm{kg}$ oil eq & $2.2 \mathrm{E}^{-05}$ & 9.569 \\
\hline Metal depletion & $\mathrm{kg} \mathrm{Fe} \mathrm{eq}$ & 0.00021 & 0.225 \\
\hline Water depletion & $\mathrm{m}^{3}$ & 0.00311 & 0.014 \\
\hline
\end{tabular}

(45\%) and freshwater eco-toxicity (212.45\%) generated by wood WtE plant were lower than the national grid, whereas impacts to terrestrial eco-toxicity (47919\%), marine eco-toxicity (200.3\%) and freshwater eutrophication $(18061.56 \%)$ generated by wood $\mathrm{WtE}$ plant were higher than the national grid.

Generating $1 \mathrm{kWh}$ from wood WtE plant created lesser impacts to resource availability than the national grid, which produced a huge impact on fossil depletion, which was $9.569 \mathrm{~kg}$ oil eq $(100 \%)$ higher compared to wood WtE plant with only $2.2 \mathrm{E}^{-05} \mathrm{~kg}$ oil eq due to electricity generation in Malaysia being dominated by fossil fuels such as natural gas, coal and oil. Generating $1 \mathrm{kWh}$ electricity by national grid contributed $99.91 \%$ higher in term of metal depletion and $77.79 \%$ higher to water depletion than wood $\mathrm{WtE}$ plant.

\section{Potential of WtE as Renewable Energy}

The government of Malaysia has been promoting renewable energy (RE) resources such as biogas, biomass, hydro and solar since the $8^{\text {th }}$ Malaysia Plan (2001-2005). RE was added to the national 
Table 3. Malaysia's cumulative total RE target.

\begin{tabular}{|c|c|c|c|c|c|c|c|c|}
\hline \multirow{2}{*}{ Year } & \multicolumn{7}{|c|}{ Targeted cumulative total RE (MW) } & Annual RE generation \\
\cline { 2 - 9 } & Biogas & Biomass & $\begin{array}{c}\text { Biomass } \\
\text { (solid waste) }\end{array}$ & Small hydro & Solar PV & Total & $\begin{array}{c}\text { RE mix } \\
(\%)\end{array}$ \\
\hline 2017 & 155 & 500 & 280 & 400 & 105 & 1440 & 5385 & 5 \\
\hline 2020 & 240 & 800 & 360 & 490 & 190 & 2080 & 11246 & 9 \\
\hline 2030 & 410 & 1340 & 390 & 490 & 1370 & 4000 & 17232 & 12 \\
\hline
\end{tabular}

electricity mix due to the rise of climate change as a global issue. Table 3 stated the outcome and target of cumulative total RE in National Renewable Energy Policy 2010.

Since Malaysia has pledged to cut the country's carbon emissions intensity based on the GDP by up to $45 \%$ by 2030 relative to 2005 value, where $35 \%$ on an unconditional basis with a further $10 \%$ condition upon climate finance, technology transfer and capacity building during the 21st United Nations Framework Convention on Climate Change (UNFCCC), massive transformation should be taken to develop the national grid toward greener sources $[15,16]$.

Malaysia's government aimed to increase the share of RE progressively in the national electricity mix for reducing carbon emissions as the highest carbon emissions were contributed to by the energy sector. However, the targeted cumulative total RE was not achieved due to output intermittency, location and system constraints, as well as technology development in Malaysia. Recently, the total cumulative total RE was far from the target and only achieved about $35 \%$ of the targeted cumulative total RE. Based on the target set by the Minister of Energy, Green Technology and Water, cumulative total RE should achieve $1440 \mathrm{MW}$, where $10.76 \%$ of RE was contributed by biogas, $34.72 \%$ by biomass, $19.44 \%$ by solid waste, $27,78 \%$ by small hydro and $7.3 \%$ by solar PV. Until 2017 there was only $514.44 \mathrm{MW}$ of cumulative total RE. The largest share was contributed to by solar PV, which was $66.8 \%$ of the cumulative total RE. $15.7 \%$ was from biomass while $10.2 \%$ of current RE was from biogas. $5.9 \%$ of RE was from mini hydro. There was only $1.4 \%$ of cumulative total RE contributed by solid waste, which utilized waste wood for electricity generation.

$31.9 \mathrm{~g} \mathrm{CO}_{2}$ eq of $\mathrm{GHG}$ emissions are emitted for every $\mathrm{kWh}$ of electricity generated by the wood $\mathrm{WtE}$ plant. Based on work done by the Intergovernmental
Panel on Climate Change in 2014, carbon dioxide equivalent $\left(\mathrm{CO}_{2}\right.$ eq $)$ findings on biogenic $\mathrm{CO}_{2}$ emissions and albedo effect of biomass power plant is $27 \mathrm{~g} \mathrm{CO}_{2}$ $\mathrm{eq} / \mathrm{kWh}$ [17]. This value does not consider the emissions of infrastructure and supply chains, while a biomass power plant emitted 10-101 g CO, eq GHG emissions for every $\mathrm{kWh}$ of electricity generation as reported by the World Nuclear Association [18]. The life cycle greenhouse gas emissions for biomass electricity generator are varied from 14 to $35 \mathrm{~g} \mathrm{CO}_{2} \mathrm{eq} / \mathrm{kWh}$ as reported by Sovacool (2008) [19]. The percentage of carbon emissions from $\mathrm{WtE}$ is $96.1 \%$ lower than the carbon emission generated from the electricity generation mix of the current national grid as more than $90 \%$ of the electricity generation mix in Malaysia is composed of fossil fuels. As reported by the Malaysia Energy Commission, electricity mix Malaysia is dominant by $41 \%$ of coal and $46.3 \%$ of natural gas. Hydropower contributed $10.7 \%$ to the generation mix at the end of 2015 [7]. Coal power plants emitted an average of $820 \mathrm{~g} \mathrm{CO}_{2}$ eq while gas power plants emitted $490 \mathrm{~g} \mathrm{CO}_{2}$ eq of $\mathrm{GHG}$ emissions for $1 \mathrm{kWh}$ electricity generation [8]. The value for emissions of GHG is much lower in wood WtE due to biogenic $\mathrm{CO}_{2}$ emissions considered in this case study. Biogenic and fossil $\mathrm{CO}_{2}$ emissions are not equated in this case as combustion of wood waste does not increase the amount of carbon in the global carbon cycle. WtE could be the potential source for RE generation as it produced as low as $31.9 \mathrm{~g} \mathrm{CO}_{2}$ eq $\mathrm{GHG}$ emissions for every $\mathrm{kWh}$ of electricity generation. Malaysia aimed to achieve $9 \%$ of RE in the generation mix by 2020 and $12 \%$ by 2030. If Malaysia succeeds in achieving the target set by the Sustainable Energy Development Authority by introducing $\mathrm{WtE}$ as a potential RE source from biomass, there will be an avoidance of 928,000 tonnes $\mathrm{CO}_{2}$ eq of GHG emissions annually beginning in 2020, and in 2030 there will be an avoidance of 1,384,000 tonnes

Table 4. The potential of $\mathrm{CO} 2$ avoidance as RE target is achieved.

\begin{tabular}{|c|c|c|c|c|}
\hline Year & $\begin{array}{c}\text { WtE generation } \\
(\mathrm{GWh})\end{array}$ & $\begin{array}{c}\text { GHG emissions with current } \\
\text { electricity mix (tonnes of } \\
\mathrm{CO}_{2} \text { eq) }\end{array}$ & $\begin{array}{c}\text { GHG emissions with } \\
\text { WtE (tonnes of } \mathrm{CO}_{2} \text { eq) }\end{array}$ & $\begin{array}{c}\text { GHG emissions avoidance with targeted } \\
\text { RE capacity and WtE as potential source } \\
\text { (tonnes of } \mathrm{CO}_{2} \text { eq) }\end{array}$ \\
\hline 2020 & 1160 & 951200 & 23200 & 928000 \\
\hline 2030 & 1730 & 1418600 & 34600 & 1384000 \\
\hline
\end{tabular}


$\mathrm{CO}_{2}$ eq of GHG emissions annually. These will ultimately help Malaysia cut the country's carbon emissions intensity as the highest carbon emissions were contributed by the energy sector in Malaysia.

\section{Conclusions}

Although WtE technologies are effective in solid waste management and electricity generation, the installation of a WtE plant in Malaysia, a developing country, is still limited. In order to study the potential of implementing $\mathrm{WtE}$ technology in Malaysia, LCA methodology was applied to assess a WtE plant which, was the only one currently involved in the FiT mechanism introduced by government under biomass-solid waste category from environmental perspective.

The biomass-fired power plant that utilized wood waste as fuel produced only $31.9 \mathrm{~g} \mathrm{CO}_{2}$ eq in generating $1 \mathrm{kWh}$ of electricity. Its $\mathrm{GHG}$ emissions was much lower than the national electivity grid, which was dominated by a fossil fuel-fired power plant. However, the biomass-fired power plant would produce more impacts on the environment than the national grid for every $\mathrm{kWh}$ of electricity generation in term of ozone depletion, ionizing radiation, terrestrial eco-toxicity, agricultural land occupation, urban land occupation, natural land transformation, marine ecotoxicity and freshwater eutrophication.

The government of Malaysia had been promoting the use of RE where biomass and solid waste were included in generation of RE. The government aimed to achieve $1440 \mathrm{MW}$ of cumulative total RE by 2017 , where $34.72 \%$ was contributed by biomass and $19.44 \%$ by solid waste, but there was only $514.44 \mathrm{MW}$ of cumulative total RE achieved in 2017. There was only $1.4 \%$ of cumulative total RE contributed by solid waste, which utilized waste wood for electricity generation and $15.7 \%$ from biomass. If Malaysia succeeded in achieving the RE target set by the Sustainable Energy Development Authority, there could be an avoidance of 928,000 tonnes $\mathrm{CO}_{2}$ eq of GHG emissions annually after 2020 and $1,384,000$ tonnes $\mathrm{CO}_{2}$ eq of $\mathrm{GHG}$ emissions annually after 2030. The implementation of WtE technologies could be seen as a potential drive to reduce greenhouse gas emissions and act a source of RE toward green growth and sustainable development of Malaysia.

\section{Acknowledgements}

The authors wish to thank the Department of Civil Engineering, Faculty of Engineering, and University of Malaya (UM), Malaysia for their financial support to carry out this research project research project for master's degree. Thanks, are also due to the paper mill for their great support during our information collection.
The project was funded under project nos. BK020-2015 and RF004A-2018 and RP023A-16SUS.

\section{Conflict of Interest}

The authors declare no conflict of interest.

\section{References}

1. Solid Waste Management Transformation Initiatives: Malaysian Achievements. Available online: http:// nehapmalaysia.moh.gov.my/wp-content/uploads/2016/03/ Paper-2-Solid-Waste.pdf (accessed on $1^{\text {st }}$ March 2018).

2. NATIONAL SOLID WASTE MANAGEMENT DEPARTMENT. Survey on SW Composition, Characteristics \& Existing Practice of SW Recycling in Malaysia. Ministry of Urban Wellbeing, Housing and Local Government: Putrajaya, Malaysia, 2013.

3. TOSIN O.S., SOLA A., AISHA K. State-level Assessment of the Waste-to-Energy Potential (via Incineration) of Municipal Solid Wastes in Nigeria. Journal of Cleaner Production, Volume 164, 804, 2017.

4. MUNISH K.C., KWOK G., JACKSON R.B., PRATSON L.F. The Potential of Waste-To-Energy in Reducing GHG Emissions. Carbon Management, 3 (2), 133, 2014.

5. WANG Y., YAN Y., CHEN G., ZUO P., YIN P. Effectiveness of Waste-To-Energy Approaches in China: From the Perspective of Greenhouse Gas Emission Reduction. Journal of Cleaner Production, Volume 163, 99, 2017.

6. PAN S.Y., DU M.A., HUANG I.T., LIU I.H., CHANG E.E., CHIANG P.C. Strategies on Implementation of WasteTo-Energy (WTE) Supply Chain for Circular Economy System: A review. Journal of Cleaner Production, 108 (Part A), 409, 2015.

7. ENERGY COMMISSION MALAYSIA. Malaysia Energy Statistics Handbook 2016. Malaysia Energy Commission: Putrajaya, Malaysia, 2016.

8. OUDA O.K.M., RAZA S.A., NIZAMI A.S., REHAN M., AL-WAKED R., KORRES N.E. Waste-To-Energy Potential: A Case Study of Saudi Arabia. Renewable and Sustainable Energy Reviews, Volume 61, 328, 2017.

9. OUDA O.K.M., CEKIRGE H.M., RAZA S.A. An Assessment of the Potential Contribution from Waste-ToEnergy Facilities to Electricity Demand in Saudi Arabia. Energy Conversion and Management, 75, 402, 2013.

10. MINISTRY OF ENERGY, GREEN TECHNOLOGY AND WATER. Handbook on the Malaysian Feed-in-Tariff for the Promotion of Renewable Energy. Ministry of Energy, Green Technology and Water: Putrajaya, Malaysia, 2011.

11. AZMAN A.Y., RAHMAN A.A., RAHMAN, BAKAR N.A., HANAFFI F., KHAMIS A. Study of Renewable Energy Potential in Malaysia. Proceedings of $1^{\text {st }}$ Conference on Clean Energy and Technology (CET), 170, 2011.

12. MALEK S. Waste-to-Energy in Eastern and South Eastern Europe. Ed. Karagiannidis A. Springer-Verlag Berlin Heidelberg New York: New York, 2012.

13. DZIKUĆ M, PIWOWAR A. Life Cycle Assessment As An Eco-Management Tool within the Power Industry. Pol. J. Environ. Stud., 24 (6), 2381, 2015. 
14. ZHOU Z.Z., TANG Y.J., YONG C., NI M.J., BUEKENS A. Waste-To-Energy: A Review of Life Cycle Assessment and Its Extension Methods. Waste Management \& Research, 1-14, 2017.

15. ONN C.C., NURUOL S., YUEN C.W., LOO S.C., SUHANA K., AHMAD F.R., MOHAMED R.K., SUMIANI Y. Greenhouse Gas Emissions Associated with Electric Vehicle Charging: The Impact of Electricity Generation Mix in A Developing Country. Transportation Research, Part D, 2017.

16. Malaysia Pledges to Cut $\mathrm{CO}_{2}$ Emissions Intensity by $45 \%$ by 2030. Available online: http://www.channelnewsasia. com (accessed on $18^{\text {th }}$ December 2017).
17. IPCC WORKING GROUP III. Mitigation of Climate Change, Annex III: Technology - Specific Cost and Performance Parameters. Intergovernmental Panel on Climate Change: German, 2014.

18. WORLD NUCLEAR ASSOCIATION. Comparison of Lifecycle Greenhouse Gas Emissions of Various Electricity Generation Sources. World Nuclear Association: London, UK, 2010.

19. SOVACOOL B.K. Valuing the Greenhouse Gas Emissions from Nuclear Power: A Critical Survey. Energy Policy, 36 (8), 2950, 2008. 